\title{
Novel Solution for Improving the Hydrocarbon Production Utilizing Chemical Injection
}

\author{
Amjed Hassan* \\ King Fahd University of Petroleum \& Minerals, Saudi Arabia
}

Submission: December 12, 2019; Published: January 06, 2020

*Corresponding author: Amjed Hassan, King Fahd University of Petroleum \& Minerals, Saudi Arabia

\begin{abstract}
Hydrocarbon production is an expensive operation, several techniques are applied to improve the production while minimizing the operational cost. Enhanced oil recovery (EOR) methods and well treatment techniques are utilized to maximize the hydrocarbon recovery using several types of injected chemicals. This paper presents new solutions to increase the hydrocarbon production using in-situ generation of surfactants and heat at reservoir condition. The presented techniques showed a very effective performance for increasing the oil recovery and decreasing the operational cost. The improvements in rock productivity ranges between 40 and $70 \%$, based on the rock type and the injected volume. A reduction of $30 \%$ could be achieved in the costs of hydrocarbon production or well treatment. The developed techniques can be applied for well stimulation as well as enhanced hydrocarbon recovery applications.
\end{abstract}

Keywords: Enhanced oil recovery, Hydrocarbon production; Natural energy; Chemical stability; Oil production; Environmental

\section{Introduction}

Enhanced oil recovery (EOR) processes are applied to create favorable flow conditions for increasing the hydrocarbon production [1]. EOR methods include reducing the interfacial tension, wettability alteration, oil swelling or oil viscosity reduction [2]. Also, the EOR processes are used to support the natural energy in the reservoir which can result in reducing the reservoir depletion and maximizing the ultimate oil recovery. In general, EOR techniques can be classified into three groups; chemical flooding, thermal methods, and gas injection techniques [1]. Chemical enhanced oil recovery (CEOR) includes processes in which chemicals are injected to improve the oil production utilizing different recovery mechanisms [3]. However, the main disadvantages of this method are the chemical stability, higher injection pressure, and the operational cost. Also, the injected surfactant can reduce the integrity of well completion due to the interaction between the injected fluids and the well completion [3].

In addition, carbon dioxide flooding is considered as one of the most effective techniques for enhancing oil recovery. However, $\mathrm{CO}_{2}$ flooding process experiences gravity override and viscous fingering which decrease the sweep efficiency. Therefore, many investigators were motivated to look for foam techniques, which involve the injection of $\mathrm{CO}_{2}$ with solution of a $\mathrm{CO}_{2}$-foaming agent
[4]. The main disadvantages of this technology are the availability of natural $\mathrm{CO}_{2}$ sources, corrosion of wells and field surface facilities environmental and safety problems. In-situ generation of $\mathrm{CO}_{2}$ at the wellbore condition can be an effective technique that can eliminate the negative impacts of $\mathrm{CO}_{2}$ injection [5].

This paper presents new techniques of in-situ generation of active agents at downhole condition using environmentally friendly chemicals. The active agent is used to refer to surfactant, heat, or gas. Those active agents can be generated at reservoir condition by using proper type of chemicals. The amount of the active agents depends on the type and concentration of the injected chemicals. In-situ generation of surfactant or heat can result in minimizing the impact of those agents on the well completion by reducing the contact time between those elements and the downhole facilities. Also, the technique of in-situ generation can increase the treatment efficiency by concentrating the active agents on the target formations, which minimizes the losses into undesired formations. Consequently, the total cost can be significantly reduced.

\section{Materials and Methods}

Thermochemical fluids were injected into different rock samples to improve the rock productivity. The injected chemicals 
were able to generate heat and pressure inside the treated rocks. In general, the thermochemical fluids are non-corrosive, non-toxic, and cheap [6]. Theoretically, the heat capacity of these fluids is very high comparing to the water capacity. The following equation illustrates the chemical reactions that control heat generation using thermochemical fluids is [7]:

$$
A(\text { liquid / gas })+B(\text { liquid / gas }) \Leftrightarrow C(\text { gas })+Q(\text { heat })
$$

To start the reaction, fluid A should be added to fluid $\mathrm{B}$, then, a significant heat will be generated due to the chemical reaction. This reaction will occur only at certain condition, i.e. a trigger factor is required to activate the reaction.

\section{Results and Discussion}

The injected chemicals showed effective performance for improving the core productivity. The improvement in rock productivity was evaluated using the pressure profiles before and after the treatment. Constant flow rate was applied in all injection treatments, and the produced fluids were collected with time. The rock productivity was calculated as the ratio between the flow rate and the pressure drop across the treated sample. Then, the improvement in productivity was estimated by comparing the rock productivity pre- and post the chemical injection.

The improvements in core productivity ranges between 40 and $70 \%$, based on the rocktype and the injected volume. Increasing the treatment volume led to increase the productivity enhancement, till reach a maximum treatment volume beyond which no considerable improvement was observed. For all samples, the optimum injection volume was found to be 1.5 pore volume, that injected in three equal cycles. The duration of each cycle can be determined based on the pressure profiles, and sufficient time should be provided to the tight rocks, to ensure good chemical penetration inside the tight rocks.

The treatment performance showed a strong dependence on the rock type. The minerals composition of each rock can affect the petrophysical properties and then affect the productivity improvements. In general, the treatment performance increases as the rock permeability increases. Also, the presence of clay minerals showed minor impact on the treatment efficiency. Overall, the chemical treatment presents a potential performance for improving the productivity of tight formation as well as the low permeable formations. A reduction of $30 \%$ could be achieved in the costs of hydrocarbon production or well treatment.

\section{Conclusion}

In this work, new chemical treatment is presented to improve the productivity of hydrocarbon reservoirs. The used fluids are non-corrosive, non-toxic, cheap and environmentally friendly chemicals. The performance of the presented treatment was evaluated using different rock types. The improvements in rock productivity ranges between 40 and $70 \%$, based on the rock type and the injected volume. Strong relationship was observed between the treatment performance and the rock permeability. A reduction of $30 \%$ could be achieved in the costs of hydrocarbon production or well treatment. Overall, the chemical treatment presents a potential performance for improving the productivity of tight formation as well as the low permeable formations.

\section{References}

1. Green DW, Willhite GP (1998) Enhanced oil recovery. Richardson, TX: Henry L. Doherty Memorial Fund of AIME, Society of Petroleum Engineers, 6: 143-154.

2. Lake LW, Johns R, Rossen WR, Pope GA (2014) Fundamentals of enhanced oil recovery.

3. Sheng J (2010) Modern chemical enhanced oil recovery: theory and practice. Gulf Professional Publishing, USA.

4. Chang SH, Grigg RB (1999) Effects of foam quality and flow rate on $\mathrm{CO}_{2}$-foam behavior at reservoir temperature and pressure. SPE Reservoir Evaluation \& Engineering 2(3): 248-254.

5. Hassan AM, Al-Hashim HS (2020) Oil Recovery Mechanisms During Sequential Injection of Chelating Agent Solutions into Carbonate Rocks. Journal of Energy Resource Technology 142(1).

6. Van Essen VM, Zondag HA, Gores J, Bleijendaal LPJ, Bakker M, et al. (2009) Characterization of $\mathrm{MgSO}_{4}$ hydrate for thermochemical seasonal heat storage. Journal of solar energy engineering 131(4).

7. Hassan AM, Mahmoud MA, Al-Majed AA, Al-Nakhli AR, Bataweel MA (2019) Water blockage removal and productivity index enhancement by injecting thermochemical fluids in tight sandstone formations. Journal of Petroleum Science and Engineering 182: 106298. 
Your next submission with Juniper Publishers will reach you the below assets

- Quality Editorial service

- Swift Peer Review

- Reprints availability

- E-prints Service

- Manuscript Podcast for convenient understanding

- Global attainment for your research

- Manuscript accessibility in different formats ( Pdf, E-pub, Full Text, Audio)

- Unceasing customer service

Track the below URL for one-step submission https://juniperpublishers.com/online-submission.php 